\title{
立体トラス形並列アームの実システムと穴の機構学*
}

\author{
田中正夫*1, \\ 瀬口靖幸*1, \\ 花原 和 之*2 \\ 山口智 久*3, \\ 野田将之*4 \\ 藤田 雅 成*5
}

\section{Prototype of Truss-type Parallel Arm and Its Kinematics}

\author{
Masao TANAKA, Yasuyuki SEGUCHI, Kazuyuki HANAHARA, \\ Tomohisa YAMAGUCHI, Masayuki NODA, and Masashige FUJITA
}

\begin{abstract}
The truss-type parallel arm has been proposed as a flexible arm with a large number of DOFs and has been discussed from a conceptual point of view. Toward the realization of this arm system, its practical structure as a link mechanism is proposed and the kinematics of a prototype is studied by introducing relative offset between the passive rotational joints connecting the active prismatic members at the nodes. A kinematical equation of motion is formulated in the total form as well as in the incremental form. The motion of the prototype is demonstrated through an experimental unit as well as numerical simulation.
\end{abstract}

Key Words: Robotics, Multidegree-of-Freedom System, Mechanism, Simulation, Kinematics, Truss, Parallel Manipulator, Robot Arm

\section{1. 緒言}

現在，産業用ロボットの主流となっている直列形口 ボットアームについては多くの研究が行われてきた が，並列形ロボットアームのそれは極めて少ない。亚 列形アームの運動能力の利用は, 1964 年の Stewart の論文(1)にも見られ，彼の名前を冠したプラットフォ 一ム注，並列形アームの代表的なものとなっている。

このタイプのアームの研究は, 1970 年代上り進めら れ，1980年代にはいってからは，その数も增えつつあ $ろ^{(2)-(8)}$.

立体トラス形アームは，大形宇宙棈造物の分野で注 目を集めている展開トラス撆造 ${ }^{(9)(10)}$ を高多自由度なア 一ムとして発展させたものである(11). トラス形アーム は立体静定トラスの部材を，伸縮可能な可变長部材で 置換したもので，本質的に䒚列形の機構となってい る.三浦らのグループは，可変立体トラス(VGT) 棈成 のトラス形アームの運動能力について検討してお

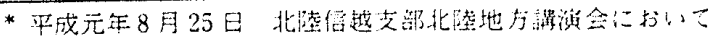
䛍演，源镐受付 昭和63年11月28日。

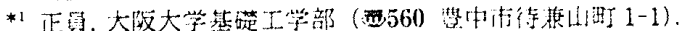

*2 学生员, 大陑大学大学院.

*3 学生員, 大阪大学大学院 (現在 シャープ㑣)

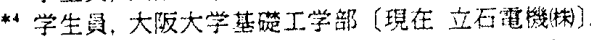

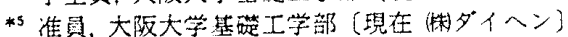

$り^{(9)(12)}$, 著者らはへリカルマスト構成のトラス形アー

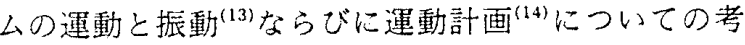
察を通じて，トラス形アームが多面的に高度の機能を 有することを確認してきた。

これまでの研究は，次章初頭で述べるようにア一ム の部材が理想的な点で連結されたトラス構造をとるこ とを想定した初期的な研究であったが，トラス形の並 列アームシステムを具体化するにあたっては，より詳 細はメカニズムを含めた考察が必要となる。本報では， ヘリカルマスト構成のトラス形アームを対象に, 実用 化のための試作プロトタイプモデル(以下，単にプロ トシステムとよぶ)とそれに基づく機構学について検 討を加える。

\section{2. トラス形アームの概念モデル}

トラス形アームが, 複数の可变辰部材が大きさのな い理想的な節点で，回転自由な状態で連結されてい る，理想的なトラスとして実現されたものを概念モデ ルと呼び, 次章以降で議論するプロトシステムと区別 する、トラス形アームの構成と概念モデルによる渾動 の記述については既に報告したが(13)，本報の主題であ るプロトシステムによる場合との比較のため, 以下に 䉮殚に説明しておく。 
2・1 アームの搆成 ここて取り上げるトラス形 アーム洨、へリカルマストと呼代れる柆体静定トラス のトポロジを持ち、基本構成単位注図 1 (a)儿示方 3 部材からなるモジュールである。このモジュールを図 1(b)に示すように三つ重枕たユニットの一次元的な 繰返し上り，図1(c)に示すア一幼構成される。

モジュールにはベース側から順に番号をつける。モ ジュールnの頂点に番号 $n$ を，3本の部材に㳉それぞ れベース側節点の番号の順に $n 1, n 2, n 3$ の番号を付 す.ここで, 部材 $n 1$ は, 直立したアームの縦部材であ る.アームベースに法節点のみが存在するが,これに はー2, - - 1,0 の各番号を割り付汸る.アームベースの 図心に固定したシステム座標系Cでみたモジュール $n$ の頂点座標ベクトル $X_{n}=\left[x_{n}, y_{n}, z_{n}\right]^{r}, 3$ 本の部材 $n 1, n 2, n 3$ の部材長をまとめて, ベクトル $L_{n}=\left[l_{n 1}\right.$, $\left.l_{n 2}, l_{n 3}\right]^{T}$ で表すこととする。

$2 \cdot 2$ 概念モデルに基つく運動の記逊 概念モデ ルにおいて，モジュール $n(n=1,2, \cdots, N)$ の姿勢を 表すものは, 頂点の位置 $X_{n}$ のみであり，モジュール の部材長ベクトル $L_{n}$ との間には, 次の幾何学的関係 が成り立つ。

$$
l_{n i}=\left[\left(X_{n}-X_{n-4+i}\right)^{T}\left(X_{n}-X_{n-4+i}\right)\right]^{1 / 2} i=1,2,3
$$

これは, 式( 2 )の上うな形式で表せ,運動学の基琁と なる。
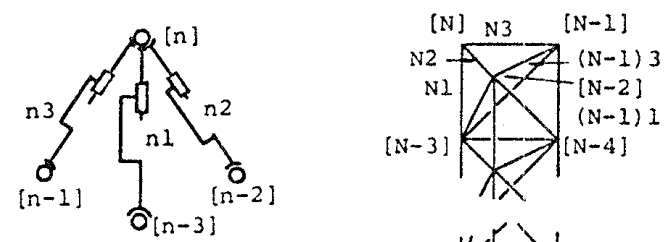

(a) モジュール
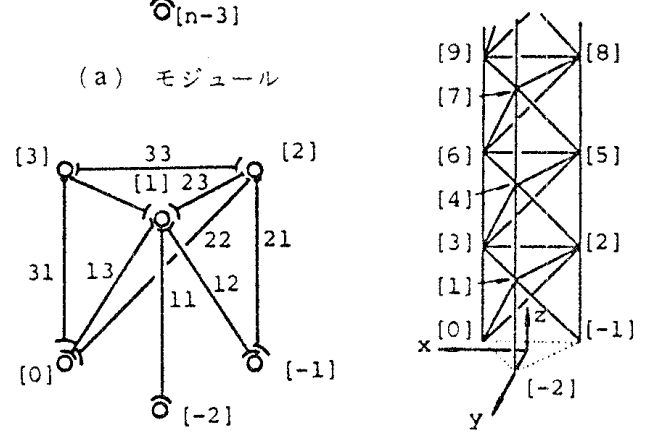

(b) $Z$ (ニット 1

(c) トラ又崕アー- -

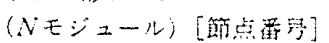

図 1 トラス形アームの溉念搆成。

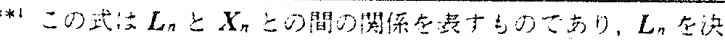

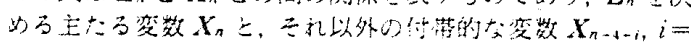

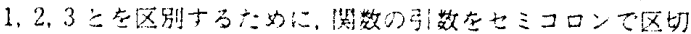

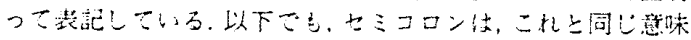
で用いるものとナる。
}

$$
L_{n}=L\left(X_{n}: X_{n-4+i}, i=1,2,3\right)
$$

この逆関係の次式(3)

$$
X_{n}=X\left(L_{n}: X_{n-4+i}, i=1,2,3\right)
$$

が,覑運動学の基礎式であり,ア一ムベース側からの 再㩆的表現となっている。

運動の增分形変記は, 式 (2)あるいは(3)の全微分 関係上り導加れる。今の場合, 式 (2), 具体的には式 (1)の全微分

$$
d L_{n}=\sum_{i=1}^{4} \frac{\partial L}{\partial X_{n-4+i}} d X_{n-4+i}
$$

より，次式のように整理できる。

$$
d \boldsymbol{L}=\boldsymbol{J}_{L X} d X
$$

ここで, $X=\left[X_{1}^{T}, \cdots, X_{N}^{T}\right]^{T}$ は, ア一ム全体の節点座 標べクトル, $\boldsymbol{L}=\left[\boldsymbol{L}_{1}^{T}, \cdots, \boldsymbol{L}_{N}^{T}\right]^{T}$ は全体部材長べクト ルであり，ヤコビ行列 $J_{L X}$ は, $3 \times 3$ の小行列よりなる ブロック下三角行列である。式( 5 )の逆関倸を求める ヤコビ行列 $J_{X L}=J_{L X}^{-1}$ を式（4)より求めることも可能 である(11)。

\section{3. プロトシステムの構成}

$3 \cdot 1$ 節点部の構成 トラス形アームの概念モデ ルにおいては，アームが理想的なトラス構造として構 成された状況在考えているので，6本の部材が回転自 由に連結导れ，かつその回転中心が一致することとな つている、ボールジョイントのような通常の回転ジョ イントは 2 リンク対偶であり，トラス形アームのよう に6本のリンク(部材)を概念モデルの条件を満足する ように連結することは容易なことではない。

複数の部材が集中して連結される部分(以下，節点 部)の瑇成考える場合，各部材の回転中心が一致す ることが，概念モデルによる連動記述がそのまま成立 するための条件である，例えば，図2に示す多数の平 行リンクを用い机代，この条件を達成することも理論 的には可能であるが，あまりにも複雑であると言わざ るを得ない。そこで，部材毎の回転中心間に偏心を許

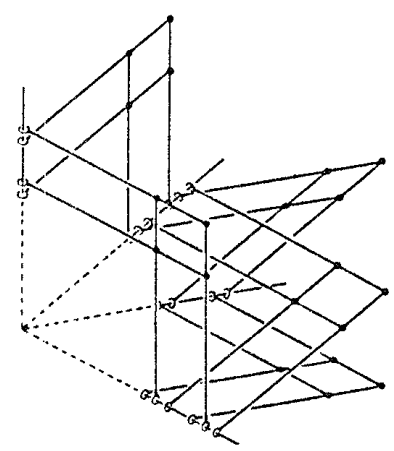

四 2 平行リンクを用いる節点部の構成 
容するような棈成を考える必要が生じる。すなるち， 図3(a)に示すような，節点部に部材を連結するため の節点ブックを導入し，これと各部材を2リンク回 転対偶で連結するアームの基本構想を考える。

$3 \cdot 2$ 自由度の調整この段階で, 部材長を与え ればアームの知が一意に定まり，各部材長は独立に 調節可能でるという,トラス形ア一ムの持つ基本的 性質が，保持されるよう検討せ㸚ばならない。これは，

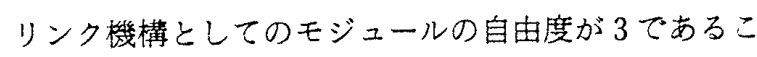
とに㷌着される。

リンクを構成するすべての対偶が 2 リンク刘偶であ る立体リンク機構の自由度は, 次のグリュブラーの 式(15)により算定できる。

$$
F=6(M-J-1)+\sum_{i=1}^{\prime} f_{i}
$$

ここで, $M$ 泣リンクの数, $J$ は対偶の数, $f_{i}$ は対偶 $i$ の自由度である。図 $3(a)$ (任意のモジュールは, 図 4 (a)に示すリンク機構をなしており，その自由度は $F=6(8-9-1)+(3 \cdot 6+1 \cdot 3)=9$ となり, 必要な自由度 数 3 に対して 6 白由度が過剩となっている。図 4(b) は, 緹部材 $n 1$ の節点部 $n$ 側の対偶が取り除かれ, た 一ス側対偶(図中の)は部材軸回りの回転を拘束し 2 自 由度としたものである。このリンク機構の自由度は， $F=6(7-8-1)+(3 \cdot 2+2 \cdot 3+1 \cdot 3)=3$ である.グリュ ブラーの式は吟味が必要であるが, 図 $4(\mathrm{~b})$ のリンク 機棈の自由度が 3 であることは，容易に確認できる。

こうして得られたプロトシステムでは, 縦部材 $n 1$ と節点部 $n$ の節点ブロックが一体となっており，以下 では，節点プロックを特に区別することなく，縦部材 の一部として扱うこととする。図 $3(\mathrm{~b})$ 泣，こうして構

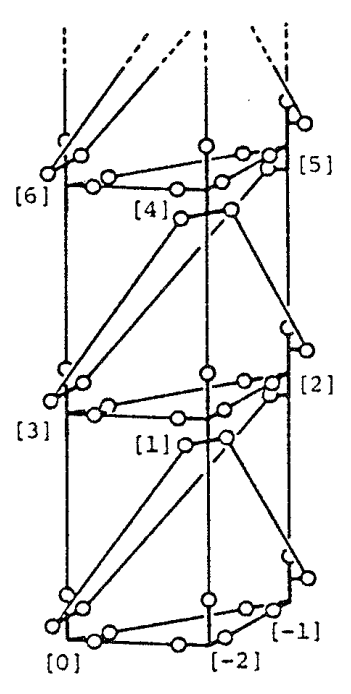

(a) 回転ジョイントの配琵

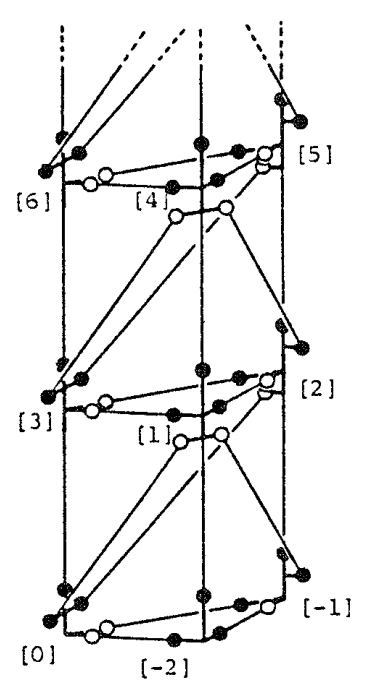

(b) 四転ジョイントの兒由度配分

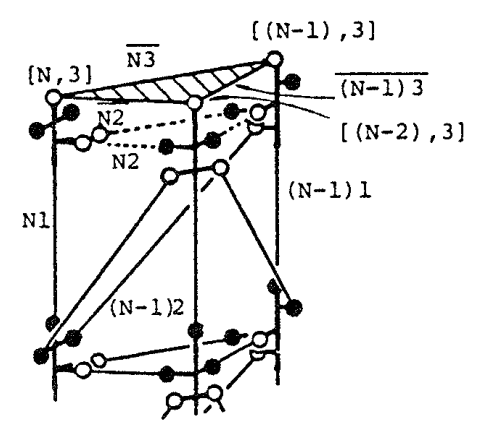

(C) 手先部心台坐

図 3 トラス形アームのプロトシステムの楧成( ○: 3 自由

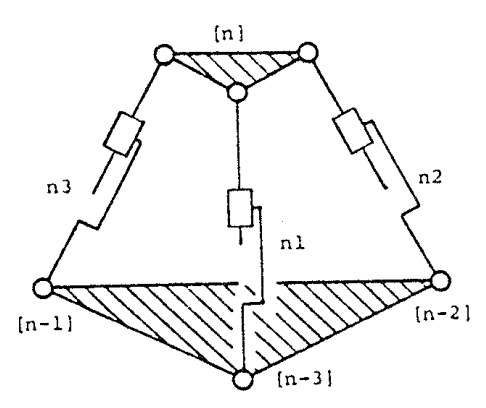

$F=6(8-9-1)+(3 * 6+1 * 3)=9$

(a) 基本棈浩

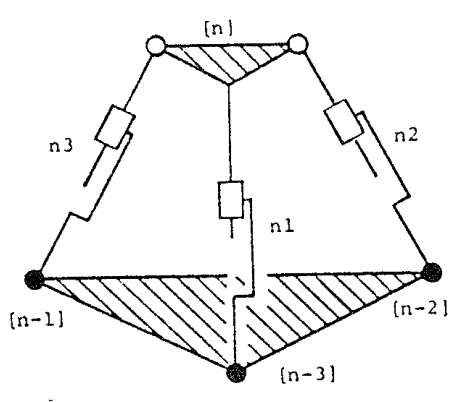

$F=6(7-8-1)+(3 * 2+2 * 3+1 * 3)=3$

(b) 自时惯配行

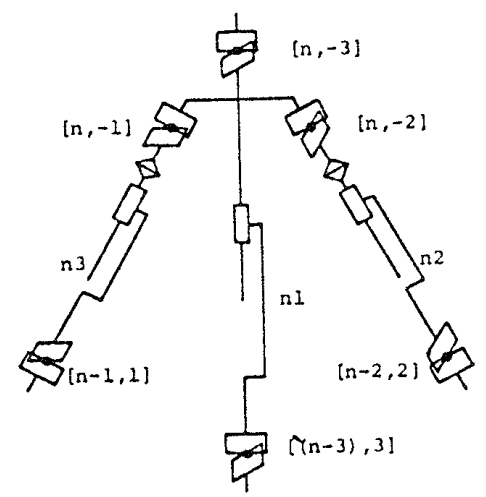

(c) プロトシステム

図4プロトシステムのモジュールの棈成 
成されたトラス形アームの回転刘偶の自由度配分を示 したものである。

$3 \cdot 3$ 手先部の台座 アーム最上部儿位置する三 つの節点, $N, N-1, N-2$ にいたる編部材先端には, 3 回転自由度を持つボールジョイント配置し，手先 部の台座となるプレートを支持する(図 3(c))。この ため, 図中破線で示した 3 部材，N3，N2，(N-1)3 仡 取り除き，台座の各辺がこれに替る。なお，簡単のため に，台座支持節点がつくる三角形は，アームベースの 成す正三角形と合同としておく。

このようにして構成したトラス形アームのモデル を，プロトシステムと呼び，概念モデルと区別して， 次章ではこのプロトシステムの運動の記述について考 える。

\section{4. プロトシステムの運動学}

ジョイントの回転中心間に偏心を許容したプロトシ ステムの，機椪学的運動を考える。プロトシステムに おいては，一部 2 自由度の回転ジョイントが用いられ るが, 本章ではこのジョイントにユニバーサルジョイ ントを想定して議論を進める.すなわち，図 4(b)のモ ジュールに，図 4(c)の構成を考えることになる。

$4 \cdot 1$ 節点の番号付け 概念モデルでは, 節点部 に一つの節点(回転ジョイント中心)を考えればよい が,プロトシステムで伩, 図 3(b)に示すように, 五つ の節点を考えなければならない，節点部 $n$ と $n^{\prime} と を$ 連結する部材の節点部 $n$ 側ジョイントの回転中心の 節点に番号 $n^{\prime}$ と $n$ との差 $a=n^{\prime}-n$ を第 2 の指標と して， $n, a$ なる対を番号として付与する。なお，節点 部 $n$ に洨， $n,-3$ なる節点は存在しないが，便宜上節 点 $n, 3$ と同じ位置に存在すると考えておく.節点部 $n$ を代表する点として，節点 $n, 3=n,-3$ 用いる。部 材の番号，ならびに全体座標系 $C$ の定義は，2・1節と

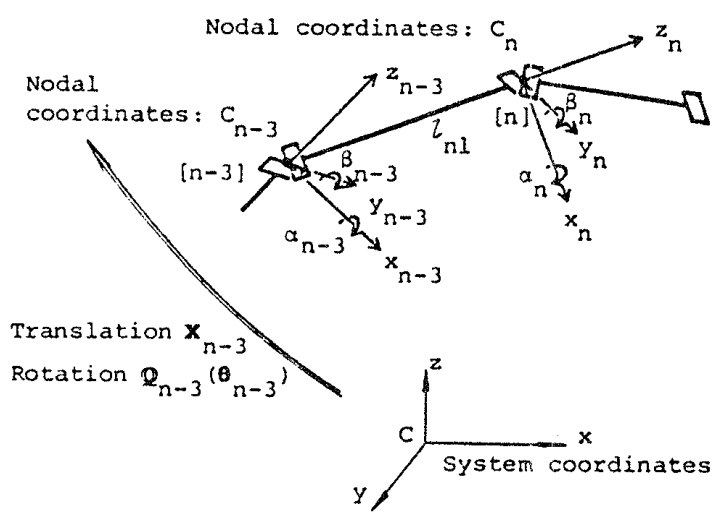

図 5 全体座標系 $C$ と節点座嫩系 $C_{n}$
同じである。

$4 \cdot 2$ モジュールの姿势 概念モデルにおいては, モジュールの姿勢を頂点nの位置のみで表すことが できたが，プロトシステムでは，節点部が大きさを持 つため，節点部 $n$ の位置と方向を考える必要がある。

節点部 $n$ の方向を定義するために, 節点座標系 $C_{n}$ を定義する(図 5)。節点部 $n$ の代表点 $n(=n,-3)$ に 原点をとり, モジュール $n$ と $n+3$ の縦部材, $n 1$ と $(n+3) 1$ が直螕をなすときの，ユニバーサルジョイン ト $n(=n, 3=n,-3)$ の部材 $(n+3) 1$ お゙よび $n 1$ 側の 回転軸方向に，それぞれ $x_{n}, y_{n}$ 軸を定め，また，部材 $n 1$ から $(n+3) 1$ の方向に $z_{n}$ 軸をとる。座標系 $C$ と $C_{n}$ との間の次の座標変换式

$$
X=Q_{n} \cdot X^{(n)}+X_{n}
$$

を考える.ここで, 屃添字 $(n)$ は節点座標系 $C_{n}$ を参照 したことを示士。節点部 $n$ の位置は, 式 ( 7 )の並進量 $X_{n}$ で表し, 方向は回転行列 $Q_{n}$ を定義する回転べク トル $\theta_{n}$ で表寸。例えば，回転角 $\theta_{n}$ として，ロール角 $\phi_{n}$, ピッチ角 $\theta_{n}, \exists$ 一角 $\Psi_{n}$ を用いるならば, 回転行 列 $\boldsymbol{Q}_{n}$ としてロール・ピッチ・ヨー変換行列 $R P Y^{(16) を}$ 用いればよい。すなわち，

$$
\begin{aligned}
& Q_{n}=Q_{n}\left(\theta_{n}\right)=\operatorname{RPY}\left(\phi_{n}, \theta_{n}, \Psi_{n}\right) \\
& \boldsymbol{\theta}_{n}=\left[\begin{array}{ll}
\Psi_{n}, & \theta_{n}, \phi_{n}
\end{array}\right]^{T}
\end{aligned}
$$

$4 \cdot 3$ アームの姿勢＼cjkstart概念モデルの式(1)に対怘 する幾何学的閔係

$$
\begin{aligned}
& l_{n i}=\left[\left(X_{n,(i-4)}-X_{(n-4+i), i}\right)^{T}\right. \\
& \left.\quad\left(X_{n,(i-4)}-X_{(n-4+i), i}\right)\right]^{1 / 2} \quad i=1,2,3
\end{aligned}
$$

が，運動記述の出発点となる，節点 $n, a$ の位置 $X_{n, a}$ は，節点部 $n$ の代表点の位置 $X_{n}$ と，そこからの偏心 量の和として表される.偏心量は,アームの運動によ らない定数 $S_{a}$ として, 節点座標系を参照した形で与 えられるので,

$$
X_{n, a}=Q_{n} S_{a}+X_{n}
$$

と書ける。式(10)を考慮すれば, 式(9)の基本関係は 形式的に次のように整理できる。

$$
\begin{aligned}
L_{n}= & L_{n}^{X Q}\left\{X_{n}, Q_{n}\left(\theta_{n}\right): X_{n-3}, X_{n-2},\right. \\
& \left.Q_{n-2}\left(\theta_{n-2}\right), X_{n-1}, Q_{n-1}\left(\theta_{n-1}\right)\right\}
\end{aligned}
$$

なお，偏心量 $S_{a}$ は定数であるので，省略してある. 式 (11)の関係を求めたことで, 概念モデルの式(2)に対 応する関係が求められたかに思えるかもしれないが, モジュールクのベース側節点部の位置と方向が既知 となったとき，部材長 $L_{n}$ の 3 成分を与えても，頂点

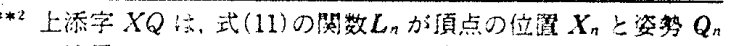

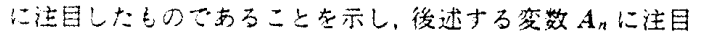
した式(17)の $L_{n}$ と区别するためいものである。他の関数に

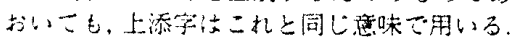


部 $n$ の位置と方向の 6 成分を式(11)だけで定めるこ とはできない。これを定めるためには，以下のような 考察が必要亡なる。

図5に示した節点座標系 $C_{n-3}$ の $x_{n-3}, y_{n-3}$ の各軸 回りの回転各 $\alpha_{n-3}, \beta_{n-3}$, および緥部材 $n 1$ の長さ $l_{n 1}$ を用いれば、節点座標系 $C_{n-3}$ を参照した $X_{n}$ と $Q_{n}$ が次のように求方うる。

$$
\boldsymbol{X}_{n}^{(n-3)}=\boldsymbol{Q}_{n}^{(n-3)} \cdot\left[0,0, l_{n 1}\right]^{T}
$$
ただし，

$$
\begin{aligned}
& \boldsymbol{Q}_{n}^{(n-3)}=\boldsymbol{Q}_{n}\left(\boldsymbol{\theta}_{n}^{(n-3)}\right) \\
& \boldsymbol{\theta}_{n}^{(n-3)}=\left[\alpha_{n-3}, \beta_{n-3}, 0\right]^{T}
\end{aligned}
$$

これを更に全体座標系に変換して次式を得る。

$$
\begin{aligned}
& X_{n}=Q_{n-3} \cdot X_{n}^{(n-3)}+X_{n-3} \cdots \cdots \cdots \cdots \cdots(14 \cdot \mathrm{a}) \\
& Q_{n}\left(\theta_{n}\right)=Q_{n-3}\left(\theta_{n-3}\right) \cdot Q_{n}^{(n-3)}\left(\theta_{n}^{(n-3)}\right) \cdots \cdots(14 \cdot \mathrm{b})
\end{aligned}
$$

ここで, 補助的な変数 $A_{n}$

$$
A_{n}=\left[\alpha_{n-3}, \beta_{n-3}, l_{n 1}\right]^{T}
$$

を尊入し, 以上の関係式を整理する。式(14)の変換式 は, 次の関数形式と理解できる。

$$
\begin{aligned}
& X_{n}=X_{n}^{A}\left(A_{n} ; X_{n-3}, Q_{n-3}\left(\theta_{n-3}\right)\right) \cdots \cdots \cdots(16 \cdot \mathrm{a}) \\
& \boldsymbol{Q}_{n}=\boldsymbol{Q}_{n}^{A}\left(A_{n} ; \boldsymbol{Q}_{n-3}\left(\boldsymbol{\theta}_{n-3}\right)\right) \cdots \cdots \cdots \cdots \cdots \cdots(16 \cdot \mathrm{b})
\end{aligned}
$$

式 $(16 \cdot b)$ は, 行列値関数であるが, 式 $(8)$ と組合せ て考えれば，回転ベクトル $\theta_{n} か ゙ ， A_{n}$ および $\theta_{n-3}$ に 依存することを示したものとわかる。また，式(11)も 補助变数 $A_{n}$ を用いて

$$
L_{n}=L_{n}^{A}\left(A_{n} ; X_{n-i}, Q_{n-i}\left(\theta_{n-i}\right), i=1,2,3\right)
$$

と書ける。概念モデルにおける運動学の基本式 (2)と (3)に対応するのが,こうして得られた式(16)と(17) である、すなわち、ア一ムを構成する任意のモジュ一 ルのベース側節点部の位置と姿勢が定められたなら ば, 部材長ベクトル $L_{n}$ の 3 成分から, 式(17)の逆関 係

$$
A_{n}=A_{n}^{L}\left(L_{n} ; X_{n-i}, \quad Q_{n-i}\left(\theta_{n-i}\right), i=1,2,3\right)
$$

として, 補助変数 $A_{n}$ が定まり, これ孝式(16)に代入 ナることて，頂点部 $n$ の位置 $X_{n}$ と方向 $\theta_{n}$ が求めら れ, 次のようになる。

$$
\begin{array}{r}
\boldsymbol{X}_{n}=\boldsymbol{X}_{n}^{L}\left(\boldsymbol{L}_{n} ; \boldsymbol{X}_{n-i}, \boldsymbol{Q}_{n-i}\left(\boldsymbol{\theta}_{n-i}\right), i=1,2,3\right) \\
\ldots \ldots \ldots \ldots(16 \cdot \mathrm{a})^{\prime} \\
\boldsymbol{Q}_{n}\left(\boldsymbol{\theta}_{n}\right)=\boldsymbol{Q}_{n}^{L}\left(\boldsymbol{L}_{n} ; \boldsymbol{X}_{n-i}, \boldsymbol{Q}_{n-i}\left(\boldsymbol{\theta}_{n-i}\right), i=1,2,3\right)
\end{array}
$$

また，頂点部の位置が指定されたときには，式(16・a) の逆関係加補助変数 $A_{n}$

$$
A_{n}=A_{n}^{X}\left(X_{n} ; X_{n-3}, Q_{n-3}\left(\theta_{n-3}\right)\right) \cdots \cdots(16 \cdot a) "
$$

を求め，これを式(17)に代入することで，必要となる 部材長 $L_{n}$ を定めることができる。この際，頂点部の
方向 $\theta_{n}$ 洨, 式 $(16 \cdot \mathrm{b})$ 加付随的に求主る。

以上のょうに, ジョイントの回転中心間に偏心を許 容したプロトシステムにおいても，アームベースの三 つの節点部 $-2,-1,0$ の位置および方向が固定され ていることから，概念モデルの場合と同様，ベース側 から逐次的にアームの姿勢が定まることがわかる。

なお，式(16)と(17)，あるいは(16)と(17)における 補助変数の意味は，以下の上うに解釈される。式(16) の関係は，モジュールの姿勢が縋部材のべース側節点 での二つの回転角 $\alpha_{n-3}, \beta_{n-3}$ と部材長 $l_{n 1}$, すなおち 補助変数 $A_{n}$ で定まることを示している。この 3 兒由 度は極座標系の成分をなしており，ア一ムの䋛部材の つながりは，図 6 に示すような極座標形ア一ムを直列 に連結したものとみなせる。この連続した極座標形ア 一ムの各々は, 先端でトラス形アームの手先部の台座 を、ボールジョイントを介して把持していることにな る。したがって、トラス形アームは 3 台の連続した極 座標形アームが, 協調して一つの台座をハンドリング している状態に対応している、モジュールnにおいて は, 緃部材 $n 1$ 以外の二つの部材の長さ $l_{n 2}, l_{n 3}$ が, $\alpha_{n-3} と \beta_{n-3}$ の 2 つ角度を調整するための自由度と なっている.

$4 \cdot 4$ 作業点の姿勢 $3 \cdot 3$ 節で述べた手先部台座 を支持するボールジョイントは, 節点 $N, N-1$, $N-2$ の代表点に位置し，部材 $N 3, N 2,(N-1) 3$ にか えて, 台座を支持する節点間の線分 $\overline{N 3}, \overline{N 2}$, $(N-1) 3$ を固定長の部材と考える. 台座支持点のなす 三角形が，アームベースのそれと合同であることから， トラス形アームの作業努勢を以下のようにして取扱

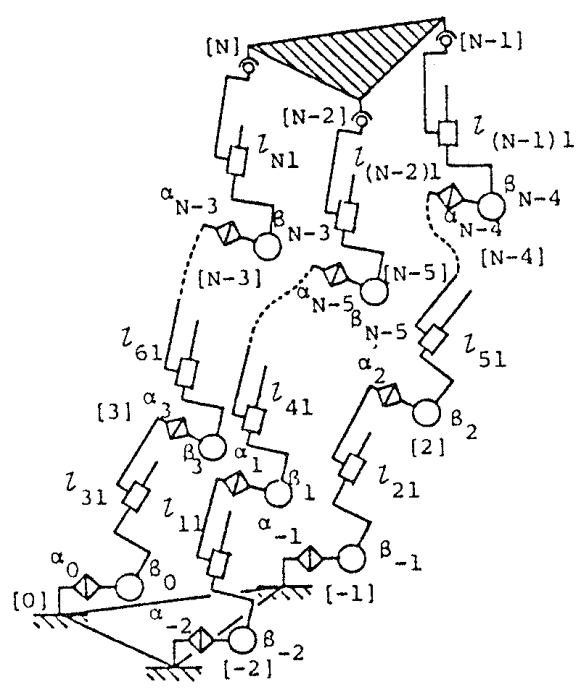

四 6 トラスト形アームにおける補助変数上 その葙列形ア一ムの協調系としての解积 
j.

アームベースかうみた台座の三角形の図心 $W$ の位

置 $\boldsymbol{X}_{w}$ と台座の方向 $\theta_{w}$ をつて,アーム片業点の 姿勢，すなわち，作業べクトル $\boldsymbol{W}$ 上する。すなわち，

$W=\left[\begin{array}{ll}X_{W}^{T}, \theta_{w}^{T}\end{array}\right]$

作業点の姿勢 $X_{W}$ と $\theta_{W}$ と，台座を支持する 3 節点の 位置 $\boldsymbol{X}_{N-2}, \boldsymbol{X}_{N-1}, \boldsymbol{X}_{N}$ との間に法,

$$
X_{N-i}=Q_{W}\left(\theta_{W}\right) \cdot X_{-i}+X_{W} \quad i=0,1,2
$$

なる関係が成立し， $X_{-2}, X_{-1}, X_{0}$ が定数であること から次のように整理できる。

$$
\boldsymbol{X}_{T}=\boldsymbol{X}_{T}(\boldsymbol{W})
$$
ただし，

$$
\boldsymbol{X}_{T}=\left[\boldsymbol{X}_{N-2}^{T}, \boldsymbol{X}_{N-1}^{T}, \boldsymbol{X}_{N}^{T}\right]^{T}
$$

また，台座支持節点間距離の拘束条件

$$
\begin{aligned}
& \left|X_{N-1}-X_{N}\right|=l \overline{N 3}=\text { const. } \\
& \left|X_{N-2}-X_{N}\right|=l \overline{N 1}=\text { const. } \cdots \cdots \\
& \left|X_{N-2}-X_{N-1}\right|=l(\overline{N-1) 3}=\text { const. }
\end{aligned}
$$

を付带させて, 式(19)の逆関係を導くことができる。

$W=W\left(X_{T}\right)$

式(16)'とこれとを組合せれば，部材長べクトルLと 作業ベクトルWとの関係を導くことができる。

\section{5. 運動の増分形記迹}

4 章で導いたアームの姿勢を表す式(16)'と作業点の 姿勢を表す式(21) とを連立すれば，運動解析が行える わけであるが，これを解析的に行うこと恔容易でなく， 具体的な運動解析心执いては，增分形の運動表記が必 要となる。

$5 \cdot 1$ アーム全体の姿勢 まず，概念モデルにお ける式(5)に対応する裴現を，式(16)から求める，二 の作業は，形式的心は

$$
\begin{aligned}
d \boldsymbol{X}_{n} & =\frac{\partial \boldsymbol{X}_{n}^{L}}{\partial \boldsymbol{L}_{n}} d \boldsymbol{L}_{n}+\sum_{i=1}^{3}\left\{\frac{\partial \boldsymbol{X}_{n}^{L}}{\partial \boldsymbol{X}_{n-i}} d \boldsymbol{X}_{n-i}\right. \\
& \left.+\frac{\partial \boldsymbol{X}_{n}^{L}}{\partial \boldsymbol{Q}_{n-i}} d \boldsymbol{Q}_{n-i}\right\} \\
d \boldsymbol{Q}_{n} & =\frac{\partial \boldsymbol{Q}_{n}^{L}}{\partial L_{n}} d \boldsymbol{L}_{n}+\sum_{i=1}^{3}\left\{\frac{\partial \boldsymbol{Q}_{n}^{L}}{\partial \boldsymbol{X}_{n-i}} d \boldsymbol{X}_{n-i}\right. \\
& \left.+\frac{\partial \boldsymbol{Q}_{n}^{l}}{\partial \boldsymbol{Q}_{n-i}} d \boldsymbol{Q}_{n-i}\right\} \ldots \ldots \ldots \ldots \ldots \ldots \ldots \ldots
\end{aligned}
$$

と書けるが，ただらに $\partial X_{n}^{t} / \partial L_{n}$ 等の倔微分係数が計 算できるわけで伎ない，式(22・a)の場合は，以下の手 順によう㱛代ならない。式(16・a)の全微分関係式を $d A_{n}$ について整理する。このdAn を式(16・b)の全微

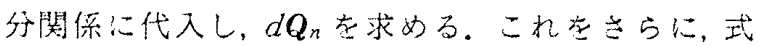

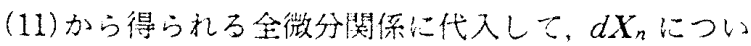
て整理することで，次式の上うに係数が求められる。

$$
\begin{aligned}
& \frac{\partial \boldsymbol{X}_{n}^{L}}{\partial \boldsymbol{L}_{n}}=\left[\frac{\partial \boldsymbol{L}_{n}^{X}}{\partial \boldsymbol{X}_{n}}+\frac{\partial \boldsymbol{L}_{n}^{X Q}}{\partial \boldsymbol{Q}_{n}} \cdot \frac{\partial \boldsymbol{Q}_{n}^{A}}{\partial \boldsymbol{A}_{n}} \cdot\left(\frac{\partial \boldsymbol{X}_{n}^{A}}{\partial \boldsymbol{A}_{n}}\right)^{-1}\right]^{-1} \\
& \frac{\partial \boldsymbol{X}_{n}^{L}}{\partial \boldsymbol{X}_{n-3}}=-\frac{\partial \boldsymbol{X}_{n}^{L}}{\partial \boldsymbol{L}_{n}}\left[\frac{\partial \boldsymbol{L}_{n}^{X Q}}{\partial \boldsymbol{X}_{n-3}}\right. \\
& \left.\quad-\frac{\partial \boldsymbol{L}_{n}^{X Q}}{\partial \boldsymbol{Q}_{n}} \cdot \frac{\partial \boldsymbol{Q}_{n}^{A}}{\partial \boldsymbol{A}_{n}} \cdot\left(\frac{\partial \boldsymbol{X}_{n}^{A}}{\partial \boldsymbol{A}_{n}}\right)^{-1} \cdot \frac{\partial \boldsymbol{X}_{n}^{A}}{\partial \boldsymbol{X}_{n-3}}\right] \\
& \frac{\partial \boldsymbol{X}_{n}^{L}}{\partial \boldsymbol{Q}_{n-3}}=-\frac{\partial \boldsymbol{X}_{n}^{L}}{\partial L_{n}}\left[\frac{\partial \boldsymbol{L}_{n}^{X}}{\partial \boldsymbol{Q}_{n}} \cdot \frac{\partial \boldsymbol{Q}_{n}^{A}}{\partial \boldsymbol{Q}_{n-3}}\right. \\
& \left.\quad-\frac{\partial \boldsymbol{L}_{n}^{X Q}}{\partial \boldsymbol{Q}_{n}} \cdot \frac{\partial \boldsymbol{Q}_{n}^{A}}{\partial \boldsymbol{A}_{n}} \cdot\left(\frac{\partial \boldsymbol{X}_{n}^{A}}{\partial \boldsymbol{A}_{n}}\right)^{-1} \cdot \frac{\partial \boldsymbol{X}_{n}^{A}}{\partial \boldsymbol{Q}_{n-3}}\right] \\
& \frac{\partial \boldsymbol{X}_{n}^{L}}{\partial \boldsymbol{X}_{n-i}}=-\frac{\partial \boldsymbol{X}_{n}^{L}}{\partial \boldsymbol{L}_{n}} \cdot \frac{\partial \boldsymbol{L}_{n}^{X Q}}{\partial \boldsymbol{X}_{n-i}} \\
& \frac{\partial \boldsymbol{X}_{n}^{L}}{\partial \boldsymbol{Q}_{n-i}}=-\frac{\partial \boldsymbol{X}_{n}^{L}}{\partial \boldsymbol{L}_{n}} \cdot \frac{\partial \boldsymbol{L}_{n}^{X Q}}{\partial \boldsymbol{Q}_{n-i}} \quad i=1,2
\end{aligned}
$$

また，式(16・b)の全微分より $d A_{n}$ を求め, 式(16・a) の全微分関係に代入して， $d X_{n}$ について整理する。こ れを式(11)の全微分に代入し， $d \boldsymbol{Q}_{n}$ に関してまとめる r,

$$
\begin{aligned}
& \frac{\partial \boldsymbol{Q}_{n}^{L}}{\partial \boldsymbol{L}_{n}}=\left[\frac{\partial \boldsymbol{L}_{n}^{X Q}}{\partial \boldsymbol{Q}_{n}}+\frac{\partial \boldsymbol{L}_{n}^{X Q}}{\partial \boldsymbol{X}_{n}} \cdot \frac{\partial \boldsymbol{X}_{n}^{A}}{\partial \boldsymbol{A}_{n}} \cdot\left(\frac{\partial \boldsymbol{Q}_{n}^{A}}{\partial \boldsymbol{A}_{n}}\right)^{-1}\right]^{-1} \\
& \frac{\partial \boldsymbol{Q}_{n}^{L}}{\partial \boldsymbol{X}_{n-3}}=-\frac{\partial \boldsymbol{Q}_{n}^{L}}{\partial \boldsymbol{L}_{n}}\left[\frac{\partial \boldsymbol{L}_{n}^{X Q}}{\partial \boldsymbol{X}_{n-3}}+\frac{\partial \boldsymbol{L}_{n}^{X Q}}{\partial \boldsymbol{X}_{n}} \cdot \frac{\partial \boldsymbol{X}_{n}^{A}}{\partial \boldsymbol{X}_{n-3}}\right] \\
& \frac{\partial \boldsymbol{Q}_{n}^{L}}{\partial \boldsymbol{Q}_{n-3}}=-\frac{\partial \boldsymbol{Q}_{n}^{L}}{\partial \boldsymbol{L}_{n}}\left[\frac{\partial \boldsymbol{L}_{n}^{X Q}}{\partial \boldsymbol{X}_{n}} \cdot \frac{\partial \boldsymbol{X}_{n}^{A}}{\partial \boldsymbol{Q}_{n-3}}\right. \\
& \left.\quad-\frac{\partial \boldsymbol{L}_{n}^{X Q}}{\partial \boldsymbol{X}_{n}} \cdot \frac{\partial \boldsymbol{X}_{n}^{A}}{\partial \boldsymbol{A}_{n}} \cdot\left(\frac{\partial \boldsymbol{Q}_{n}^{A}}{\partial \boldsymbol{A}_{n}}\right)^{-1} \cdot \frac{\partial \boldsymbol{Q}_{n}^{A}}{\partial \boldsymbol{Q}_{n-3}}\right] \\
& \frac{\partial \boldsymbol{Q}_{n}^{L}}{\partial \boldsymbol{X}_{n-1}}=-\frac{\partial \boldsymbol{Q}_{n}^{L}}{\partial \boldsymbol{L}_{n}} \cdot \frac{\partial \boldsymbol{L}_{n}^{X Q}}{\partial \boldsymbol{X}_{n-i}} \\
& \frac{\partial \boldsymbol{Q}_{n}^{L}}{\partial \boldsymbol{Q}_{n-i}}=-\frac{\partial \boldsymbol{Q}_{n}^{L}}{\partial \boldsymbol{L}_{n}} \cdot \frac{\partial \boldsymbol{L}_{n}^{X Q}}{\partial \boldsymbol{Q}_{n-i}} \quad i=1,2
\end{aligned}
$$

の上うに，式 $(22 \cdot b)$ 微分係数が求められる。

式(24)の濑化式を逐次代入し，式(22・a)のdQ 0項 を式(22・b)に上り消去すれば， $d X_{n}$ 汸， $d L_{n}, d L_{n-1}$, $\cdots, d L_{1}$ と, $d X_{-i}, d Q_{-i},(i=0,1,2)$ を用いて表され ることになる。アームベースの節点 $-i,(i=0,1,2)$ の位置と方向が固定きれていることから，アーム全体 の部材長ベクトルの增分 $d L$ と節点の位膡ベクトルの 增分 $d \boldsymbol{X}$ との閏の関係が得られる。

$$
d X=\widehat{J}_{X I} \cdot d L
$$

式(25)のヤコビ行列 $\hat{J}_{X L}$ は, $3 \times 3$ の小行列からなる ブロック下三角行列であり，この構造は，概念モデル のヤコビ行列，式（5）の $J_{X L}$ の構造と同じである.

以上の增分関係を考える際に，本来なら涂，座標変 換行列 $Q_{n}$ 等の增分ではなく，節点部の方向 $\theta_{n}$ 等の 增分を取扱小ね格ららかったが，式(25)の導出過程 では $\theta_{n}$ が $Q_{n}$ の引数としてのみ現れ，かつ，最終的に は消去きれるので， $Q_{n}$ を用いた上記の致開でも不都 合が生じないことを付記しておく。 
$5 \cdot 2$ 作業点の姿勢 作業ベクトル $W$ と部材長 ベクトルLの増分関係について考える．4・4節の式 (19)の全微分をとると, $d X_{T}=J_{X T W} \cdot d W$ ただし，

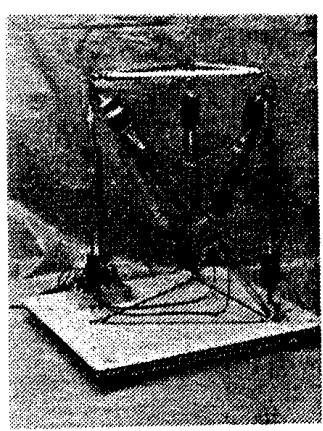

(a) 直立

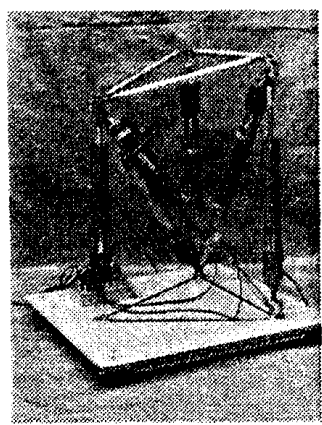

(d) 回転 ( $x$ 軸)

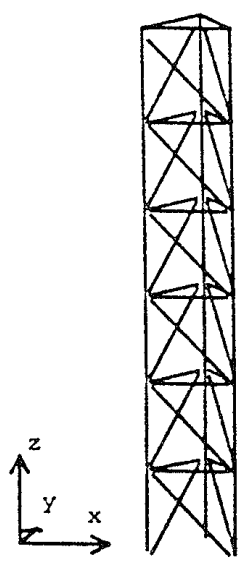

(a) 初期姿势

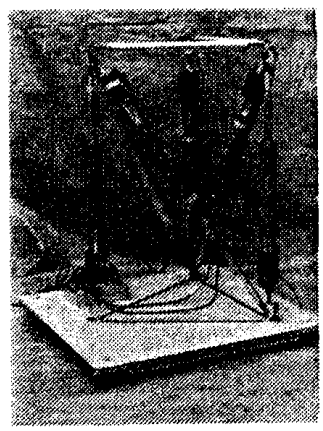

(b) 亚進 $(z$ 軸)

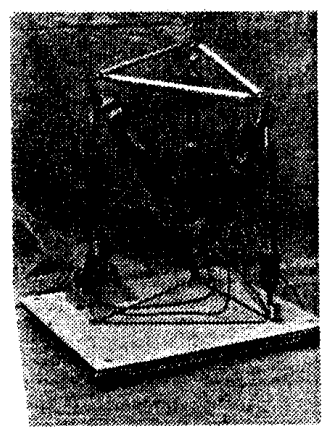

(e) 回転 $(y$ 軸)

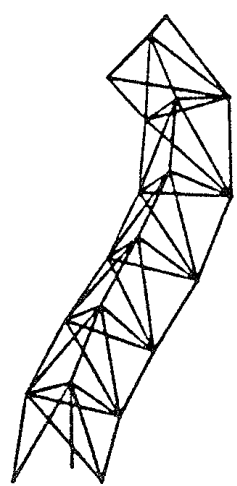

(b) 蔇念モデルに 蕉一少埸合

$$
\boldsymbol{J}_{X T W}=\left[\begin{array}{ll}
I_{3} & \partial \boldsymbol{Q}_{w} / \partial \boldsymbol{\theta}_{W} \cdot \boldsymbol{X}_{-2} \\
\boldsymbol{I}_{3} & \partial \boldsymbol{Q}_{W} / \partial \boldsymbol{\theta}_{W} \cdot \boldsymbol{X}_{-1} \\
\boldsymbol{I}_{3} & \partial \boldsymbol{Q}_{w} / \partial \boldsymbol{\theta}_{W} \cdot \boldsymbol{X}_{0}
\end{array}\right]
$$

ここで， $X_{T}$ が節点位置べトル $\boldsymbol{X}$ の一部であり,ブ 一ル行列 $B_{X T}$ を用いて

$$
\boldsymbol{X}_{T}=\boldsymbol{B}_{X T} \cdot \boldsymbol{X}
$$

と表されることから，增分関係式(25)と組合せると

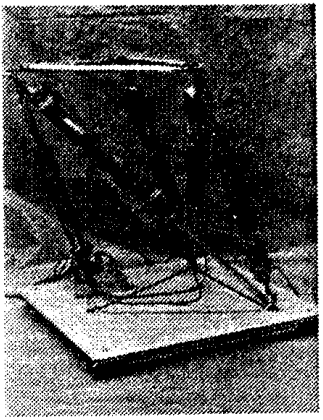

(c) 並進 ( $y$ 軸)

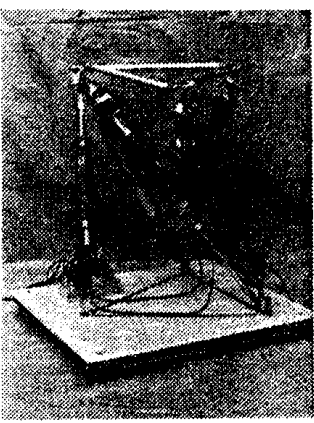

(f) 回転 ( $z$ 軸)

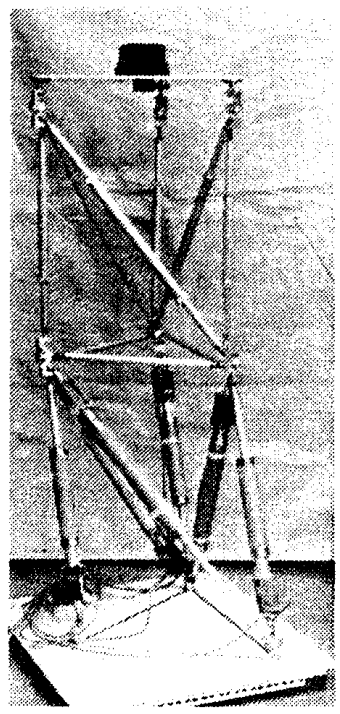

（g）亚進( $x$ 軸)

図 7 プロトシステムに基づく試作ニニットの動作列

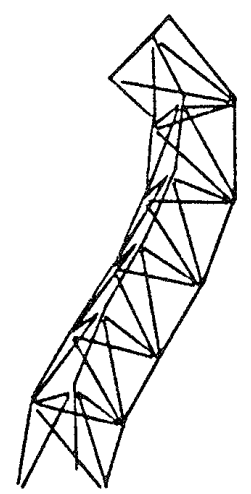

(c) プロトシスデムに

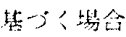

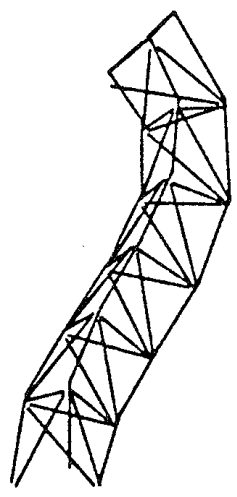

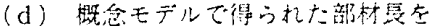
プロトシステム人力した場合

図 8 渾動シミュレーション例 


$$
\boldsymbol{J}_{X T W} \cdot d \boldsymbol{W}=d \boldsymbol{X}_{T}=\boldsymbol{B}_{X T} \cdot \widehat{\boldsymbol{J}}_{X L} \cdot d \boldsymbol{L}
$$

なる関係が得うれる。逆渾動解析で、, 与えうれた $d W$ に対して, $\left[\boldsymbol{B}_{X T} \cdot \widehat{J}_{X L}\right]$ の適当な一般化逆行列在用 いて，式(28)を解けばよい。ただし，このとき手先部の 台座の三角形の辺 $\overline{(N-1) 3}, \overline{N 1}, \overline{N 3}$ の長さが不変で あるための条件

$$
d L_{T}=B_{L T} \cdot d L=0
$$

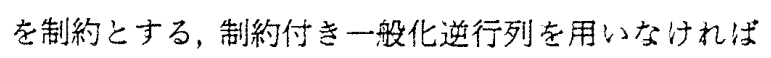
ならない(17)。なお， $\boldsymbol{B}_{L T}$ は，台座の辺にあたる部材の 長さベクトル $L_{T}=[l \overline{(N-1) 3}, l \overline{N 1}, l \overline{N 3}]^{T} を L$ から取 り出すプール行列である。

\section{6. プロトシステムの運動例}

トラス形アームの第 1 ユニットの, 緃と斜めの6 本 の部材だけを可変長とした，6自由度有するプロト システムを考える.図7(a)は，ステッピングモータに ボールネジを直結し、コンピュータによりモータをオ ープンループでコントロールすることで, 部材長を可 変とする棈造を採用し，節点部には 3 算で示したよう な偏心を持つ節点ブロックを亲部材先端に取付けて作 成した，試作ユニットを示したものである，直立した 三角柱状の姿勢，図 $7(\mathrm{a})$ を基準とし，上面の節点 1 , 2,3 を， $z$ 軸あるいは $y$ 軸方向に同じだけ並進させた 時の，試作ユニットの姿勢を示したのが，図7(b)， (c)であり， $x, y, z の$ 各軸に平行で上面の中心を通 る直線回りの回転を与えたときの姿勢が，図 7(d), (e)，(f)である. 図7(g) は，図 7(a)の第 1 ユニッ トに，第 2 ユニット(これは槽造モデルである)を重权， 手先部の台座をその先に取付けた，2工二ット構成で あり，図7(b)から（f）の場合と同じ6自由度を用い て，手先台座の作業点Wを $x$ 軸方向に並進させたと きの姿勢を示している.

次に，6ユニット，51自由度のトラス形アームを考 え，概念モデルによる運動とプロトシステムによる運 動のシミュレーションを行う。几展自由度の取扱いに は, 部材長ベクトルの增分のコークリッドノルムを最 小と寸る一般化逆行列(疑似逆行列) 庄用いる(17). 図

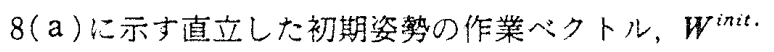
$=\left[(0[\mathrm{~m}], 0[\mathrm{~m}], 6[\mathrm{~m}])^{T},(0[\mathrm{deg}], 0[\mathrm{deg}], 0[\mathrm{deg}])^{T}\right]^{T}$ から，最終姿勢の作業べクトル $W^{f i n}=[(1,0,5)]^{r}$, $\left.(0,-45,0)^{T}\right]^{T}$ まで, 20 增分ステップで線形に変化き せたとさの，最終姿勢を図 8(b)，(c)に示す，図 8(b)は概念モデルでの結果，(c)はプロトシステム での結果である。これはどちらの場合も，增分近似に よる作業ベクトルの 20 增分ステップ㖟の偏差を第 21 增分として，最終姿势での補正をしており，それぞれ
の作業ヘクトルの偏差は、10 $10^{-5}$ 程度である、得られた 最終姿势はどららも非常に類似しており, 節点部に偏 心を許容したプロトシステムが，概念モデルとほほ同 等な動作をするようすが例証されている。

摡念モデルを用いて得られた最終状態の部材長ベク トルの値を，プロトシステムに与えて順運動解析をし て得られた姿勢を図8(d)に示す。この姿勢と図8(c) の姿勢との差異は一見したところ明確ではない.しか しながら, 図8(d)の姿勢での作業ベクトルは $W=$ $\left[(1.076,0.077,5.002)^{T},(-9.33,-41.79,-10.56)^{T}\right]^{T}$

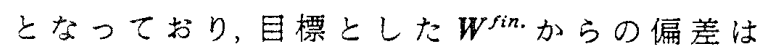
$\left[(0.076[\mathrm{~m}], 0.077[\mathrm{~m}], 0.002[\mathrm{~m}])^{T},(-9.33[\mathrm{deg}]\right.$, $\left.3.21[\mathrm{deg}],-10.56[\mathrm{deg}])^{T}\right]^{T}$ と明白であり，特に作業 点の方向で顥著である。なお，シミュレーションでは， 節点部での各ジョイントの回転中心間の偏心量とし て，直立時の緃部材の長さのほほ1割程度を想定し た。これは試作モデルの偏心量と同等な大きさである。 なお, 図 8 に示した 51 自由度のアームの場合, アポロ コンピュータDN 3000 を用いて，1増分ステップの演 算時間は，概念モデルで5.6[s]，プロトモデルで $32.1[\mathrm{~s}]$ である。

\section{7. 結言}

立体トラス形アームの概念モデルは，トラス構造の 部材を伸縮可能な可変長部材で置換したものであり， 複数の部材が一点で回転自由に連結されることにな る.この蔇念モデルをそのままに実現することは困難 であるため，各部材が節点部で偏心を許容して連結さ れるプロトシステムについての考察を行った. 3 章で はプロトシステムの構成について検討を加え，概念モ デルの持つ基本的性質が保持されるような構成を示し た。プロトシステムに基つくくトラス形アームの運動学 に必要しなる基䃈式を 4 章で定式化し， 5 章でその增 分形の表現を薄いた，導いたヤコビ行列は，ブロック 三角行例であり，概念モデルのものと同じ構造をとつ ている。また，導いた運動記述に基づき，試作ユニット の動作例と、シミュレーションによる運動解析例を示 した。 以上を通じて，トラス形並列アームをシステム として矢現するための，基整を確立することができた と考える。

\section{文献}

(1) Stewart, D., Proc. Inst. Vech. Eng., 180-1-5(1965-66). 371.

(2) Hunt. K. H., Trans. ASME J. Mech. Trans. Auto. Design, 105-4(1983), 705 .

(3) Yang, D. and Lee. T. W., Trans. ASME J. Mech. Trans. 
Auto. Design, 106-1 (1984), 191.

(4) Mohamed. M. G. and Duffy, J., Trans. ASME J. Mech. Trans. Auto. Design, 107-2 (1985), 226.

(5) Inoue. H.. 洼加 2 名. Proc. 3rd. Int. Symp. Robotics Res., (1985), 321. MIT press.

(6) Fichter, E. F., Int. J. Robotics Res., 5-2(1986), 157.

(7) Sugimoto, K., Trans. ASME, J. Mech. Trans. Auto. Design, 109-1(1987), 3.

(8) Merlet. J. P.. Proc. 3rd Int. Conf. Adranced Robotics, (1987), 125. 1FS/Springer.

(9) Miura. K...活 2 名. Acta Astronautica. 12-7/8(1985), 559 (IAF-84-394. 1984)

(10) Natori, M. and Miura. K., AIAA/ASME/ASCE/AHS 26th Struct. Siructural Dynamics and Material Conf.. (1985). AIAA-85-0727.

(11) Seguchi. Y.. 洼加 4 名. Proc. Japan-USA Symp. Flexible Automation, (1986), 251, JAACE.

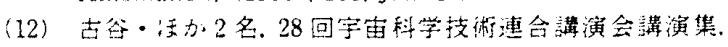
$(1984-10), 430$.

（13）瀨口・法加4名、機論, 54-503.C(1988)，1411.

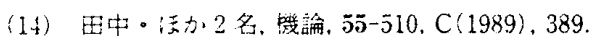

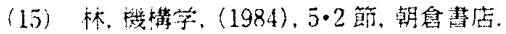

(16) Paul.R.P.(吉川訳), ロポット・マニビニレーク. (1984), 2・ 4 節, $\vec{z}$ at社.

(17) Rao, C.R. and Mitra, S.K. (泚谷・田边訳)，一般化逆行列上

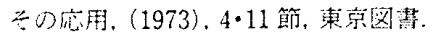

